\title{
Stress analysis of the thoracolumbar junction in the process of backward fall: An experimental study and finite element analysis
}

\author{
PEI-DONG SUN ${ }^{1,2^{*}}$, XIAO-XIANG ZHANG ${ }^{1 *}$, YUAN-WEI ZHANG $^{1 *}$, ZHE WANG $^{1}$, XIAO-YU WU ${ }^{1}$, \\ YAN-CHAO WU ${ }^{1}$, XING-LIANG YU ${ }^{1}$, HAO-RAN GAN ${ }^{1}$, XIANG-DONG LIU ${ }^{1}$, \\ ZI-ZHENG AI ${ }^{1}$, JIAN-YING HE ${ }^{1}$ and XIE-PING DONG ${ }^{1}$ \\ ${ }^{1}$ Department of Orthopedics, Jiangxi Provincial People's Hospital Affiliated to Nanchang University, \\ Nanchang, Jiangxi 330006; ${ }^{2}$ Department of Human Anatomy, Southern Medical University, \\ Guangdong Key Laboratory of Medical Biomechanics, Guangzhou, Guangdong 510515, P.R. China
}

Received December 9, 2019; Accepted April 21, 2020

DOI: $10.3892 / \mathrm{etm} .2021 .10551$

\begin{abstract}
The aim of the present study was to evaluate the biomechanical mechanism of injuries of the thoracolumbar junction by the methods of a backward fall simulation experiment and finite element (FE) analysis (FEA). In the backward fall simulation experiment, one volunteer was selected to obtain the contact force data of the sacrococcygeal region during a fall. Utilizing the fall data, the FEA simulation of the backward fall process was given to the trunk FE model to obtain the stress status of local bone structures of the thoracolumbar junction during the fall process. In the fall simulation test, the sacrococcygeal region of the volunteer landed first; the total impact time was $1.14 \pm 0.58 \mathrm{sec}$, and the impact force was up to $4,056 \pm 263 \mathrm{~N}$. The stress of thoracic (T)11 was as high as $42 \mathrm{MPa}$, that of the posterior margin and the junction of T11 was as high as $70.67 \mathrm{MPa}$, and that of the inferior articular process and the superior articular process was as high as $128 \mathrm{MPa}$. The average stress of T12 and the anterior margin of lumbar 1 was $25 \mathrm{MPa}$, and that of the endplate was as high as $21.7 \mathrm{MPa}$, which was mostly distributed in the back of the endplate and the surrounding cortex. According to the data obtained from the fall experiment as the loading condition of the FE model, the backward fall process can be simulated to improve the accuracy of FEA results. In the process of backward fall, the front edge of the vertebral body and the
\end{abstract}

Correspondence to: Dr Xie-Ping Dong, Department of Orthopedics, Jiangxi Provincial People's Hospital Affiliated to Nanchang University, 152 Aiguo Road, Nanchang, Jiangxi 330006, P.R. China

E-mail: 13576030901@139.com

*Contributed equally

Key words: thoracolumbar injury, backward fall, human musculoskeletal system, finite element analysis, in vivo experiment root of vertebral arch in the thoracolumbar junction are stress concentration areas, which have a greater risk of injury.

\section{Introduction}

Osteoporosis (OP) has become a major public health problem in the ageing population. As the thoracolumbar spine is the transitional site of the fixed thoracic $(\mathrm{T})$ spine to active lumbar (L) spine (T11-L2), it is biomechanically vulnerable to injury $(1,2)$. Low-energy injuries, such as falls, can cause compression fractures of the thoracolumbar junction in patients with OP $(2,3)$. For some patients, bed rest is required after a fracture due to surgical contraindications, such as high blood pressure or severe coronary heart disease; however, this may lead to long-term lower back pain and discomfort, kyphosis of the spine and a decline in quality of life (2). The medical and economic costs of osteoporotic compression fractures are rapidly increasing $(4,5)$. Hence, the accurate assessment of local stress in the thoracolumbar junction during a backward fall is important in further understanding the injury mechanism and may provide a reference for the future study of protective devices. However, due to the position of the thoracolumbar spine, it is difficult to directly measure the force condition during the backward fall process $(6,7)$. Nevertheless, finite element (FE) analysis (FEA) has made a significant contribution to the research and understanding of spinal mechanics. The effectiveness of spinal FEA has been confirmed in previous studies $(8,9)$. During FEA, 3D-irregular geometry is constructed, and the non-uniform materials are arranged. Next, large complex loads and motions are applied, and the contact of facet joints is simulated (10). However, due to the inherent defects of FEA, such as a large accuracy floating, the results of FE simulation must be fully validated to ensure the accuracy compared with the real-life situation (11). Hence, analysis of direct FE validation was used in the present study to ensure the accuracy of results based on an experimental test and the relative FE simulation.

In the present study, the body posture and hip contact force values in the falling process were obtained using a 
human body backward fall simulation experiment. The hip contact force and the direction measured were then used as loading conditions. These were directly given to a human body trunk FE model for quasi-static FE simulation, in order to accurately obtain the structures of the thoracolumbar junction involved in the backward fall process. The stress condition and stress concentration were then used to evaluate the injury mechanism of the local area in the process of a backward fall.

\section{Materials and methods}

Volunteer information. A healthy young man (age, 24 years; height, $172 \mathrm{~cm}$; weight, $70 \mathrm{~kg}$ ), with no past medical history of bone tumors and fractures, OP or concussion, was recruited. The current study was approved by the Ethics Committee of Jiangxi Provincial People's Hospital Affiliated to Nanchang University (Nanjing, China), and written informed consent was provided by the volunteer.

Biomechanical test of a backward fall. A 3D force table (BP400600; Advanced Mechanical Technology, Inc.) was used to record the hip force during the backward fall process. During the test, in order to protect the volunteer, a $5 \mathrm{~cm}$-thick high-density sponge with a density of $45 \mathrm{~kg} / \mathrm{m}^{3}$ was laid above the force table. The size of the sponge was $60 \times 40 \times 5 \mathrm{~cm}^{3}$, which was required to cover the surface but not exceed the edge of the platform (6). In addition, the volunteer kept their body straight, at an angle of $30^{\circ}$ to the vertical axis, and held a fixed rope that could be released at will. When the described initial state was maintained by the volunteer, the rope was released suddenly under the condition of diverting the volunteer's attention, so as to achieve the state of simulated unprepared backward fall (Fig. 1). Data acquisition frequency of the force platform was set as $50 \mathrm{~Hz}$, and the precision was $0.01 \mathrm{~N}$. The backward fall was mimicked at least three times and the impact force on the hip was collected each time. The average impact force was then calculated.

FEA. Abaqus 2016 software (Dassault Systèmes) was used to simulate the stress state of the human trunk during the process of backward fall (Fig. 2) (12). Firstly, computed tomography (CT) scan data of the volunteer were collected from a dual-source 64-slice spiral CT system (Siemens AG) at Jiangxi Provincial People's Hospital Affiliated to Nanchang University. The scan parameters were set as $120 \mathrm{kV}$ voltage and $0.625 \mathrm{~mm}$ pitch. All original CT data were stored in digital imaging communications in medicine format, and then imported into Mimics 19.0 software (Materialise NV) for reconstruction. The 3D models of overall trunk surface, vertebrae, thorax and the pelvis were separately divided and saved in stereolithography (STL) format.

The 3D models in STL format were imported into Geomagic 2016 software (3D Systems, Inc.) to be modified and exported as IGES format models. These were then imported into Hypermesh 14.0 software (Altair Engineering, Inc.) for further Boolean operation, meshing, addition of truss unit ligament structures and the endowment of each structure with validated material property parameters, to establish the final FE model of the trunk.
The linear and isotropic elasticity property of the FE model was developed, which included cortical and trabecular bone, ligament and cartilage structures, intervertebral disc and surrounding soft tissues. During the mesh procedure, seed sizes were set to $1-3 \mathrm{~mm}$, and a finer mesh size was used for the regions of interest of the thoracolumbar junction, including T11, T12 and the upper lumbar region. An almost 0.5-mm gap was used for the facet joint of lumbar vertebrae, but the non-contact condition (within the torque of $7.5 \mathrm{~N} \cdot \mathrm{m}$ ) was defined to avoid nonconvergence and decrease the expense of the FEA simulation.

The FE model was then imported into Abaqus software to set the boundary conditions and load accurate force-time parameters of the sacrococcygeal bony structures obtained using the Anybody software (Anybody Technology AS) simulation calculation. The upper thoracic margin was set as a fixed boundary condition, the loading point was set as the ischial tubercle and the loading was carried out step-by-step according to the force-time curve. The material properties and node information of bony and soft-tissue structures in the FE model are shown in Table I, and material attribute parameters of each ligament are shown in Table II. Moreover, all FE models were simulated based on quasi-static analysis by Abaqus/standard solver on a T7900 tower workstation (Dell Inc.). Regarding the AVG 75\%, if the AVG was set to 1, it meant that the stress calculation of all nodes in the display area were used for generating the average; therefore, a smoother cloud image was created. If AVG was set to $75 \%$, it meant that when the relative node variable was less than the value and the result of the node was averaged.

At FEA simulation data collection, 50 representative nodes in the stress concentration part of the thoracolumbar spine were selected to calculate the average von Mises stress value as the overall stress value of the structure.

\section{Results}

Backward fall experiment. The results of the backward fall experiment showed that the sacrococcygeal region of the volunteer landed first, and that the hip joint was at a state of flexion at this time. During the process of backward fall, the trunk was flexed at the time of landing, and the trunk was extended after landing. The total impact time of landing was $1.14 \pm 0.58 \mathrm{sec}$, and the maximum impact force was $4,056 \pm 263 \mathrm{~N}$, which is approximately six-times the body weight of the volunteer.

FE simulation of a backward fall. Under static loading, the stress of each vertebral structure decreased gradually along the spine, following the peak value of stress, which appeared at $0.4 \mathrm{sec}$ (Fig. 3), and the stress of the T11 front vertebral body was as high as $42 \mathrm{MPa}$ (Fig. 4). In addition, the stress of the T11 rear edge and pedicle junction was as high as $70.67 \mathrm{MPa}$ (Fig. 5), and the maximum stress value between the inferior articular process and upper articular process of T12 was $\sim 128 \mathrm{MPa}$ (Fig. 6). Moreover, the average stress of T12 and the front edge of L1 was $25 \mathrm{MPa}$, and the maximum stress of the end plate was $21.7 \mathrm{MPa}$, which was mainly distributed in the central and posterior part of the end plate and surrounding cortex (Figs. 6 and 7). 
Table I. Material properties of bony and soft-tissue structures of finite element analysis model.

\begin{tabular}{|c|c|c|c|c|c|c|c|}
\hline First author (year) & Structure & $\begin{array}{c}\text { Elasticity } \\
\text { modulus E (MPa) }\end{array}$ & $\begin{array}{l}\text { Poisson's } \\
\text { ratio }(v)\end{array}$ & $\begin{array}{l}\text { Number of } \\
\text { elements }\end{array}$ & $\begin{array}{l}\text { Number of } \\
\text { nodes }\end{array}$ & $\begin{array}{l}\text { Type of } \\
\text { element }\end{array}$ & (Refs.) \\
\hline $\begin{array}{l}\text { Denozière and Ku (2006), } \\
\text { El-Rich et al (2009) and } \\
\text { Moramarco et al (2010) }\end{array}$ & $\begin{array}{l}\text { Cortical } \\
\text { bone }\end{array}$ & 12,000 & 0.3 & 756,474 & 217,388 & C3D4 & $(31-33)$ \\
\hline $\begin{array}{l}\text { El-Rich et al (2009) and } \\
\text { Moramarco et al (2010) }\end{array}$ & $\begin{array}{l}\text { Cancellous } \\
\text { bone }\end{array}$ & 100 & 0.2 & 127,110 & 34,110 & C3D4 & $(31,32)$ \\
\hline $\begin{array}{l}\text { Denozière and } \mathrm{Ku}(2006) \text {, } \\
\text { El-Rich et al (2009), } \\
\text { Moramarco et al (2010) } \\
\text { and Guo and Li (2020) }\end{array}$ & Fiber ring & 450 & 0.3 & 75,790 & 22,104 & C3D4 & $(31-34)$ \\
\hline $\begin{array}{l}\text { Denozière and } \mathrm{Ku} \text { (2006) } \\
\text { and El-Rich et al (2009) }\end{array}$ & $\begin{array}{l}\text { Nucleus } \\
\text { pulposus }\end{array}$ & 1 & 0.5 & 35,510 & 10,100 & C3D4 & $(31,32)$ \\
\hline $\begin{array}{l}\text { Denozière and } \mathrm{Ku} \text { (2006), } \\
\text { Moramarco et al (2010) } \\
\text { and Guo and Li (2020) }\end{array}$ & Cartilage & 23.8 & 0.4 & 2,622 & 859 & C3D4 & $(31,33,34)$ \\
\hline $\begin{array}{l}\text { Moramarco et al (2010) } \\
\text { and Guo and Li (2020) }\end{array}$ & Soft tissue & 1.5 & 0.4 & 503,217 & 112,249 & C3D4 & $(33,34)$ \\
\hline
\end{tabular}

Table II. Material properties of ligament tissues.

\begin{tabular}{|c|c|c|c|c|c|c|c|}
\hline First author (year) & $\begin{array}{l}\text { Ligament } \\
\text { tissue }\end{array}$ & $\begin{array}{c}\text { Elasticity } \\
\text { modulus E (Mpa) }\end{array}$ & $\begin{array}{l}\text { Poisson's } \\
\text { ratio }(v)\end{array}$ & $\begin{array}{l}\text { Transverse } \\
\text { area }\left(\mathrm{mm}^{2}\right)\end{array}$ & $\begin{array}{l}\text { Number of } \\
\text { elements }\end{array}$ & $\begin{array}{l}\text { Type of } \\
\text { element }\end{array}$ & (Refs.) \\
\hline $\begin{array}{l}\text { Guo and Li (2020) and } \\
\text { Kong and Goel (2003) }\end{array}$ & $\begin{array}{l}\text { Anterior } \\
\text { longitudinal } \\
\text { ligament }\end{array}$ & 7.8 & 0.3 & 24 & 42 & Truss (T3D2) & $(34,35)$ \\
\hline Guo and Li (2020) and & $\begin{array}{l}\text { Posterior } \\
\text { longitudinal } \\
\text { ligament }\end{array}$ & 10 & 0.3 & 14.4 & 42 & Truss (T3D2) & $(34,35)$ \\
\hline Kong and Goel (2003) & & & & & & & \\
\hline $\begin{array}{l}\text { Guo and Li (2020) and } \\
\text { Kong et al (2003) flavum }\end{array}$ & Ligamentum & 15 & 0.3 & 40 & 36 & Truss (T3D2) & $(34,35)$ \\
\hline $\begin{array}{l}\text { Guo and Li (2020) and } \\
\text { Kong et al (2003) }\end{array}$ & $\begin{array}{l}\text { Supraspinous } \\
\text { ligament }\end{array}$ & 8 & 0.3 & 23 & 7 & Truss (T3D2) & $(34,35)$ \\
\hline Guo and Li (2020) & $\begin{array}{l}\text { Interspinous } \\
\text { ligaments }\end{array}$ & 10 & 0.3 & 26 & 28 & Truss (T3D2) & (34) \\
\hline Guo and Li (2020) & $\begin{array}{l}\text { Intertransverse } \\
\text { ligament }\end{array}$ & 10 & 0.3 & 3.6 & 56 & Truss (T3D2) & (34) \\
\hline Guo and Li (2020) & $\begin{array}{l}\text { Iliolumbar } \\
\text { ligament }\end{array}$ & 75 & 0.3 & 25 & 12 & Truss (T3D2) & (34) \\
\hline Guo and Li (2020) & $\begin{array}{l}\text { Sacrospinous } \\
\text { ligament }\end{array}$ & 12.6 & 0.2 & 25 & 8 & Truss (T3D2) & (34) \\
\hline Guo and Li (2020) & $\begin{array}{l}\text { Sacrotuberous } \\
\text { ligament }\end{array}$ & 33 & 0.3 & 539 & 8 & Truss (T3D2) & (34) \\
\hline Guo and Li (2020) & $\begin{array}{l}\text { Inguinal } \\
\text { ligament }\end{array}$ & 2.6 & 0.3 & 45 & 6 & Truss (T3D2) & (34) \\
\hline Kong and Goel (2003) & $\begin{array}{l}\text { Anterior } \\
\text { sacroiliac } \\
\text { ligaments }\end{array}$ & 208 & 0.2 & 25 & 20 & Truss (T3D2) & $(35)$ \\
\hline Kong and Goel (2003) & $\begin{array}{l}\text { Posterior } \\
\text { sacroiliac } \\
\text { ligament }\end{array}$ & 133 & 0.2 & 25 & 20 & Truss (T3D2) & $(35)$ \\
\hline
\end{tabular}




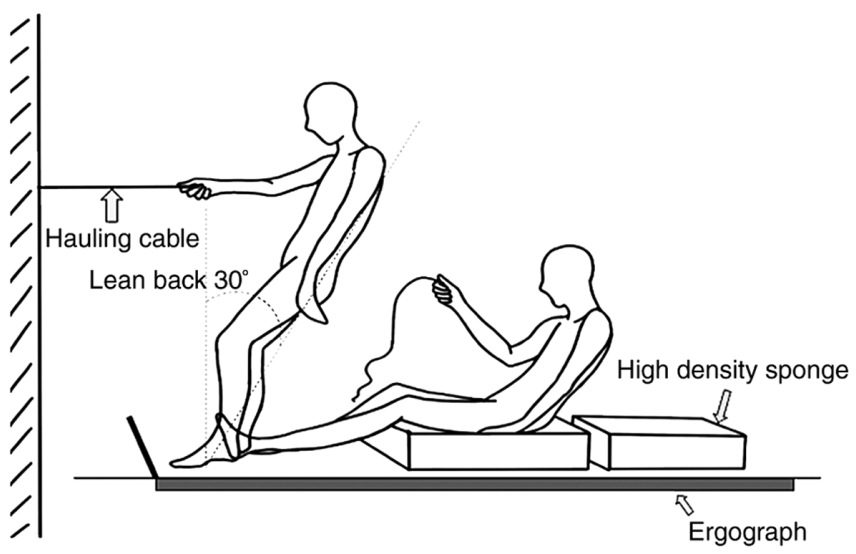

Figure 1. Schematic diagram of the backward fall experiment. All figures should be interpretable with just the figure itself and its corresponding figure legend; without having to refer back to the main text of the manuscript, similarly hereinafter.

\section{Discussion}

Thoracolumbar vertebral compression fractures caused by OP are a common and difficult problem faced by spinal surgeons, with the majority of patients being elderly (13). The direct cause of fractures is that the load acting on the vertebral body causes an internal stress which exceeds the mechanical strength of the vertebra. Therefore, regardless of bone condition, the vertebral body load is critical for the formation of fractures $(14,15)$. Previous fall experiments have mainly focused on the instantaneous posture of various parts of the body during the process of a backward fall $(16,17)$, while the impact force of a backward fall has not been as well studied. Only the instantaneous posture and the force value of the force point can be measured using force-measuring platforms. This means that the mechanical mechanism of strength transmission to the spine leading to spinal fracture after a backward fall cannot be accurately determined $(18,19)$.

Khalili et al (20) previously designed an inverted pendulum model, in which the pine was defined as a single straight rod. However, this model makes it difficult to directly obtain the stress condition of the column section during the process of a backward fall. As an effective way of performing a spinal mechanics experiment, the FE model can effectively predict the strength of spinal bone, fracture sites and stress distribution (11). However, most FE studies of fall experiments have involved simulating stress on the hip $(21,22)$, and these experimental FE models were not able to simulate the human postures involved in the process of a backward fall, which impacted on the results. Similarly, in the process of thoracolumbar segments during injury, most of the FE research methods were performed using axial impact (10). In the setting of loading conditions, due to various reasons such as limited conditions, the stress situation of subjects was not able to be added accurately. Hence, in the present study, a healthy male volunteer participated in simulating a real-life fall before a simulated fall spine stress FE experiment was carried out to obtain the accurate fall data. This provided reliable data for further understanding of the stress mechanism of the spinal structures during the backward fall process.

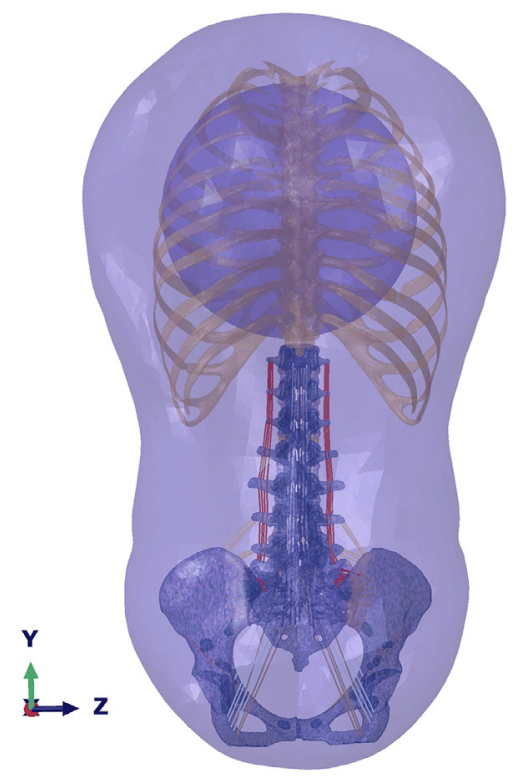

Figure 2. Finite element simulation of the backward fall experiment.

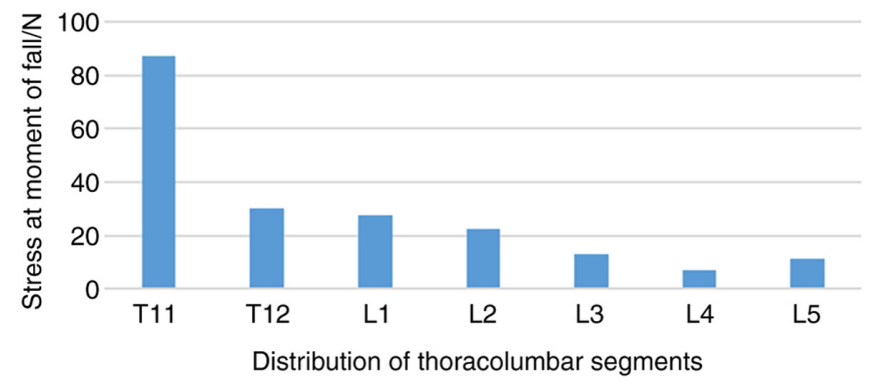

Figure 3. Stress distribution of each segment during the process of a backward fall.

In order to obtain accurate fall data, this experiment simulated the real-life backward fall process. Therein, it was found that at the moment of impact, the subject was in a flexion state with the hip joint, the sacrococcygeal region landed first, then the hip joint extended, and the chest, waist and back were stressed. The results were consistent with the fall experiment postures shown by Li et al (23) and Khalili et al (20), and the hip impact force reached 4,056 $\pm 253 \mathrm{~N}$.

For validation of the FE model, there are few prior FE studies that simulate the backward fall process to measure the stress on the spine. In the present study, an FE model was generated based on the experimental data of a backward fall, in order to analyze the stress mechanism of each segment of the thoracolumbar spine during this process. In previous studies, it was hypothesized that compression fractures accounted for the vast majority of thoracolumbar fractures caused by falls $(20,23)$. In the FE results of the present study, the stress concentration appeared in the anterior and posterior edge of T11, T12 and L1 vertebrae, upper and lower endplates, pedicle and laminae, and the peak stress appeared in the thoracolumbar segment. This was consistent with results of Gertzbein et al (24) and Nakashima et al (25) after applying axial load to the established FE model. The results of the present study complement those of Qiu et al (26), in which the established FE model of 

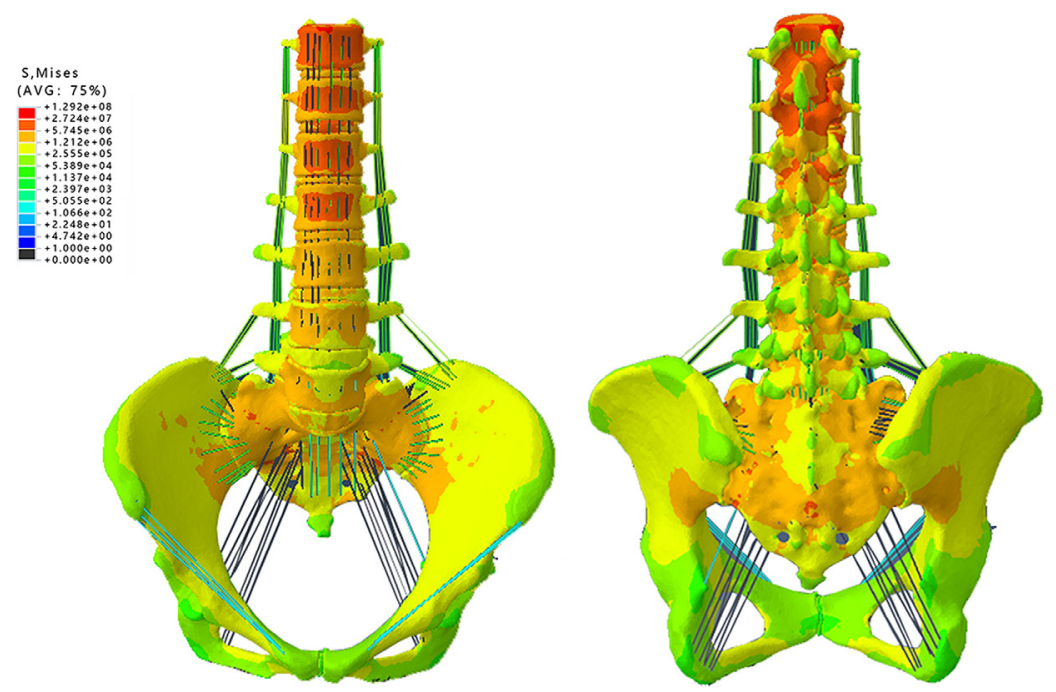

Figure 4. Stress nephogram of thoracolumbar vertebrae in falling state. S was the stress value in each direction, Mises was von Mises stress. Avg $75 \%$ was the default averaging threshold, which was used to average variables (the same below). S, stress value; Mises, von Mises stress; AVG, default averaging threshold.
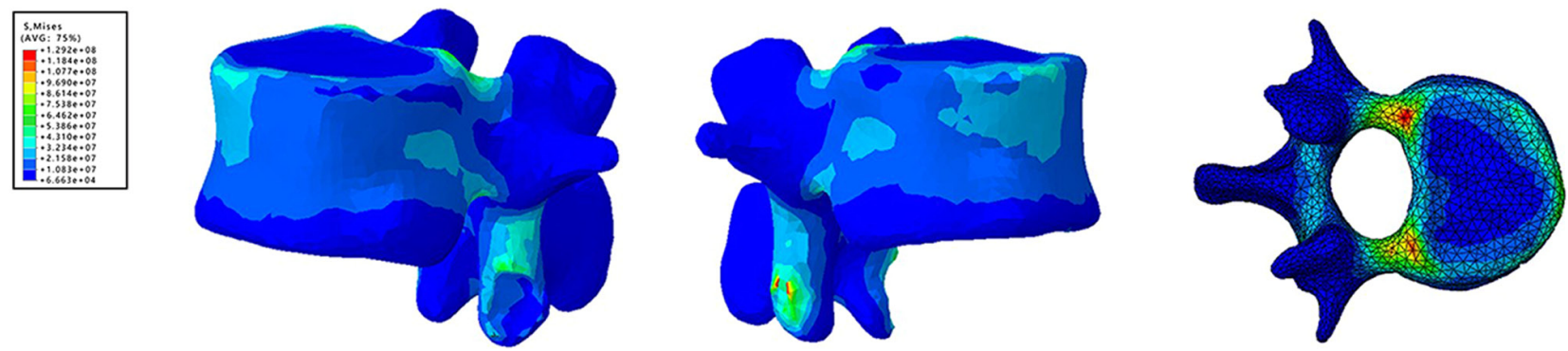

Figure 5. Stress nephogram of T11. The stress concentration at the front of the vertebral body, the junction of the pedicle and vertebral body and the lower joint was found at varying degrees, and the highest stress was found at the process of the lower joint. S, stress value; Mises, von Mises stress; AVG, default averaging threshold.
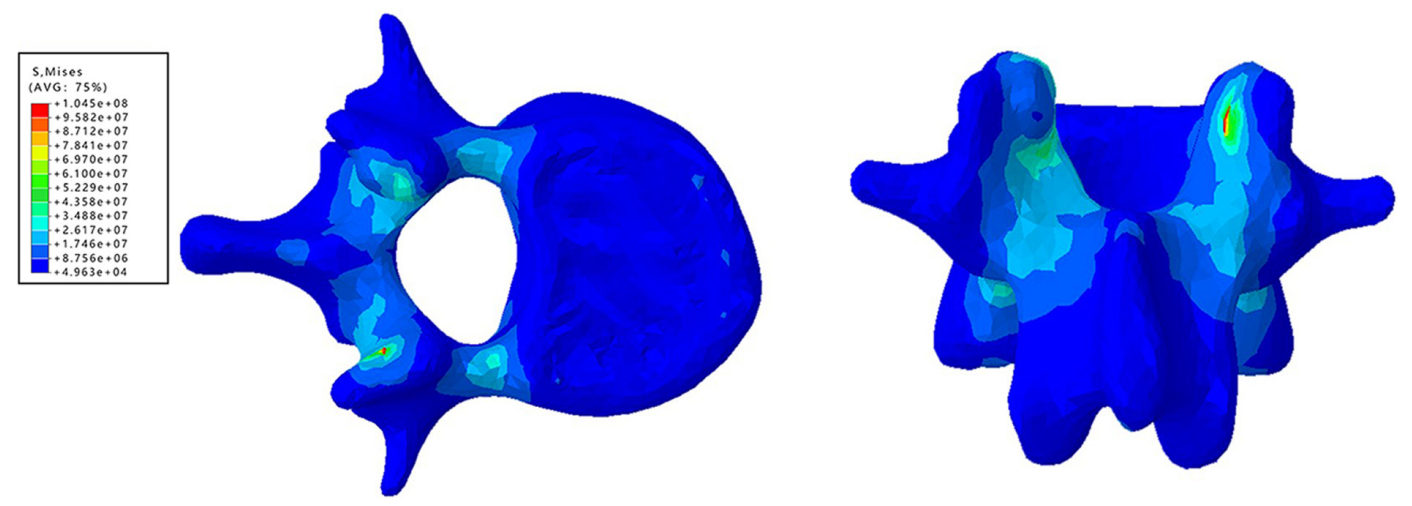

Figure 6. Stress nephogram of T12. There was a demonstratable stress concentration at the front of the vertebral body and pedicle. The stress at the cancellous bone area of endplate was greater than that at the cortical bone area, and the highest stress was found at the superior articular process. S, stress value; Mises, von Mises stress; AVG, default averaging threshold.

T12 and L1 segments were measured under vertical impact load. In the current study, the high stress areas of the upper and lower endplates were in the nucleus pulposus center and were parallel to each other, and the stress center of cancellous bone was largest near the endplate. The stress of cortical bone was concentrated in the anterior and posterior lower edge of the T12 vertebral body, and anterior and posterior upper edge of the $\mathrm{L} 1$ vertebral body. These observations were consistent with the results of lumbar FE demonstrated by Cao et al (14), which found that $>50 \%$ of vertebral body fractures occur between upper and lower endplates.

It is important to note that there was a clear stress concentration in the joint process of the lower T11, upper T12 and upper $\mathrm{L} 1$, as well as the transitional part of the pedicle, and that 

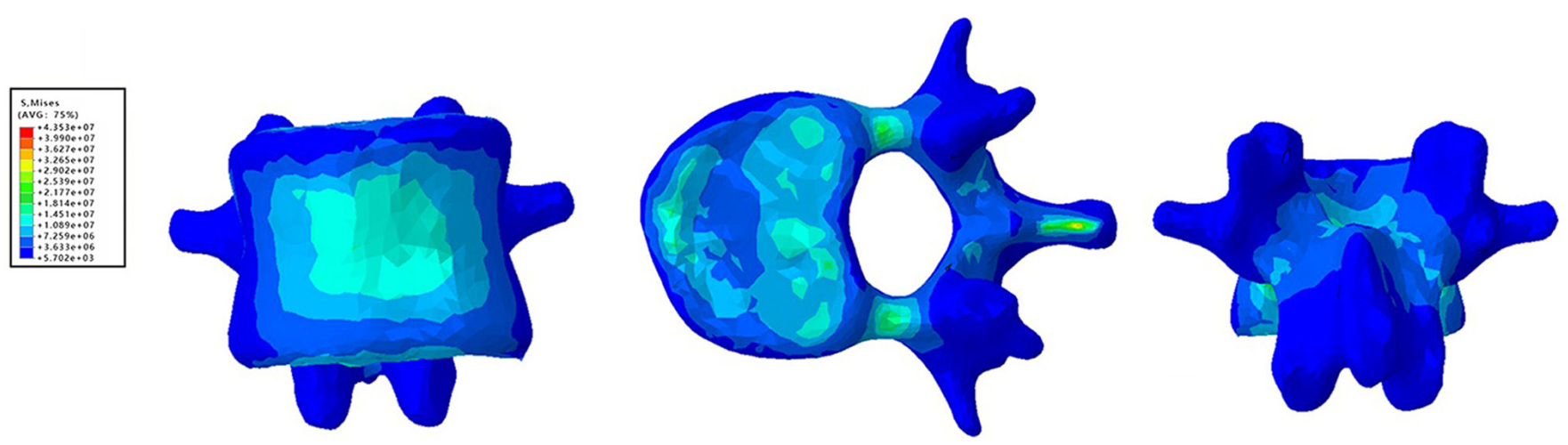

Figure 7. Stress nephogram of L1. There was a clear stress concentration at the end plate of the vertebral body, and the highest stress region of pedicle was close to that of T11 and T12. S, stress value; Mises, von Mises stress; AVG, default averaging threshold.

the stress extended to the posterior edge of the vertebral body through the pedicle. In addition, some studies have hypothesized that the interaction of articular processes causes the increase of stress and the transfer of stress along the pedicle to the vertebral body, resulting in the local stress concentration at the posterior edge of the vertebral body $(27,28)$. Moreover, Wagnac et al (29) reported that when the load of the facet was high at the level of L1-L2, the stress concentration of the pedicle root of this segment also increased, further supporting this hypothesis. In addition, Fradet et al (30) hypothesized that fractures of the pedicle could be caused by multiple loading conditions, such as forward and backward shear combined with flexion, traction combined with flexion, or traction combined with flexion and shear. Hence, it was hypothesized in the present study that the probability of fracture in these stress areas may be increased. Furthermore, by comparing the stress of different vertebrae, it has previously been found that the stress of the L4 vertebrae was significantly lower than that of the surrounding vertebrae when falling backward (30). Combined with the stress process, Gertzbein et al (24) hypothesized that the physiological curvature of vertebrae might lead to the dispersion of conduction force, resulting in the uneven distribution of vertebral force. Hence, it could be inferred from the FE results, that the risk of fracture is increased at the front vertebral body, and the upper and lower endplates of T11-L2 vertebrae after falling backward, and that fractures may occur due to the compression of the front of the vertebrae. Due to the power transmission of the upper and lower articular processes, there is also the risk of fracture at the junction of the pedicle and vertebrae of T12 and L1.

The stress distribution of thoracolumbar junction obtained in the present study showed the injury risk of this structure during the process of backward fall. Furthermore, the method of FEA combined in vivo experimental data was shown to be effective and accurate in this study. Thus, in future research, the method in the present study could be directly used for researching protective devices to prevent injury to the thoracolumbar junction from a backward fall. In addition, the protective effect and mechanism could be evaluated through an additional series of studies, which could aid in the development, optimization and improvement of protective devices for the thoracolumbar junction in OP.
Indeed, certain limitations in the current study should also be recognized and addressed. Firstly, the stress distribution of the thoracolumbar junction obtained in this study was indirectly obtained by FEA, which could provide a certain amount of error. Secondly, the sample size in this study was small, which will need to be increased for further validation. Thirdly, the current common practice is to select a volunteer of standard weight and CT scan data for modeling and simulation, which may not represent the population.

In conclusion, through the combination of FEA and human body backward fall simulation experiment, the backward fall process and the force condition of the sacrococcygeal region can be accurately obtained. The local stress state of the thoracolumbar junction during the process of a backward fall obtained in FE simulation is consistent with previous research, and there is a greater risk of fracture in the front of the T11-L1 vertebral body, the upper and lower endplates, the junction of the $\mathrm{T} 12$ and the $\mathrm{L} 1$ pedicle and vertebral body.

\section{Acknowledgements}

Not applicable.

\section{Funding}

This work was supported by the National Natural Science Foundation of China (grant nos. 81460346 and 81702160).

\section{Availability of data and materials}

The datasets used and/or analyzed during the current study are available from the corresponding author on reasonable request.

\section{Authors' contributions}

PDS, XXZ, YWZ, ZW, XYW, YCW, XLY, HRG, XDL, ZZA, JYH and XPD participated in the data collection, data analysis and data interpretation. PDS, XXZ, YWZ and XPD wrote and edited the manuscript. PDS, XXZ, YWZ and XPD contributed to the critical revision of the manuscript. PDS and XPD confirm the authenticity of all the raw data. All authors read and approved the final manuscript. 


\section{Ethics approval and consent to participate}

The current study was approved by the Ethics Committee of Jiangxi Provincial People's Hospital Affiliated to Nanchang University. Written informed consent was provided by the involved volunteer.

\section{Patient consent for publication}

Written informed consent was obtained from the volunteer for the publication of his relevant data and images.

\section{Competing interests}

The authors declare that they have no competing interests.

\section{References}

1. Lee H, Jung M, Lee KK and Lee SH: A 3D human-machine integrated design and analysis framework for squat exercises with a smith machine. Sensors (Basel) 17: 17, 2017.

2. Li B, Sun C, Zhao C, Yao X, Zhang Y, Duan H, Hao J, Guo X, Fan B, Ning G, et al: Epidemiological profile of thoracolumbar fracture (TLF) over a period of 10 years in Tianjin, China. J Spinal Cord Med 42: 178-183, 2019.

3. Hughes M, Ashour R and Rao J: Treatment of thoracolumbar burst fractures using orthosis versus no orthosis. BMJ Evid Based Med 24: 70-71, 2019.

4. Chang V and Holly LT: Bracing for thoracolumbar fractures Neurosurg Focus 37: E3, 2014.

5. Diaz JJ Jr, Cullinane DC, Altman DT, Bokhari F, Cheng JS Como J, Gunter O, Holevar M, Jerome R, Kurek SJ Jr, et al EAST Practice Management Guideline Committee: Practice management guidelines for the screening of thoracolumbar spine fracture. J Trauma 63: 709-718, 2007.

6. Sran MM and Robinovitch SN: Preventing fall-related vertebral fractures: Effect of floor stiffness on peak impact forces during backward falls. Spine 33: 1856-1862, 2008.

7. Van Toen C, Sran MM, Robinovitch SN and Cripton PA: Transmission of force in the lumbosacral spine during backward falls. Spine 37: E519-E527, 2012.

8. Gilbertson LG, Goel VK, Kong WZ and Clausen JD: Finite element methods in spine biomechanics research. Crit Rev Biomed Eng 23: 411-473, 1995.

9. Al Qahtani WMS and El-Anwar MI: Advanced Computational Methods in Bio-Mechanics. Open Access Maced J Med Sci 6 : 742-746, 2018

10. Tyndyka MA, Barron V, McHugh PE and O'Mahoney D Generation of a finite element model of the thoracolumbar spine. Acta Bioeng Biomech 9: 35-46, 2007.

11. Jones AC and Wilcox RK: Finite element analysis of the spine: Towards a framework of verification, validation and sensitivity analysis. Med Eng Phys 30: 1287-1304, 2008.

12. Karimi MT, Rabczuk T and Pourabbas B: Evaluation of the efficiency of various force configurations on scoliotic, lordotic and kyphotic curves in the subjects with scoliosis. Spine Deform 8: 361-367, 2020

13. Roy DK, O'Neill TW, Finn JD, Lunt M, Silman AJ, Felsenberg D, Armbrecht G, Banzer D, Benevolenskaya LI, Bhalla A, et al: Determinants of incident vertebral fracture in men and women: results from the European Prospective Osteoporosis Study (EPOS). Osteoporosis Int 14: 19-26, 2003.

14. Cao KD, Grimm MJ and Yang KH: Load sharing within a human lumbar vertebral body using the finite element method. Spine 26: E253-E260, 2001.

15. Imai K, Ohnishi I, Bessho M and Nakamura K: Nonlinear finite element model predicts vertebral bone strength and fracture site. Spine 31: 1789-1794, 2006.

16. Ivancic PC: Hybrid cadaveric/surrogate model of thoracolumbar spine injury due to simulated fall from height. Accid Anal Prev 59: 185-191, 2013.
17. Panjabi MM, Hoffman H, Kato Y and Cholewicki J: Superiority of incremental trauma approach in experimental burst fracture studies. Clin Biomech (Bristol, Avon) 15: 73-78, 2000.

18. Lee SC, Ding J, Prosser LA, Wexler AS and Binder-Macleod SA: A predictive mathematical model of muscle forces for children with cerebral palsy. Dev Med Child Neurol 51: 949-958, 2009.

19. Terrier A, Latypova A, Guillemin M, Parvex V and Guyen O: Dual mobility cups provide biomechanical advantages in situations at risk for dislocation: A finite element analysis. Int Orthop 41: 551-556, 2017.

20. Khalili M, Borisoff JF and Van der Loos HF: Developing safe fall strategies for lower limb exoskeletons. IEEE Int Conf Rehabil Robot 2017: 314-319, 2017.

21. Majumder S, Roychowdhury A and Pal S: Simulation of hip fracture in sideways fall using a 3D finite element model of pelvis-femur-soft tissue complex with simplified representation of whole body. Med Eng Phys 29: 1167-1178, 2007.

22. Majumder S, Roychowdhury A and Pal S: Effects of trochanteric soft tissue thickness and hip impact velocity on hip fracture in sideways fall through $3 \mathrm{D}$ finite element simulations. J Biomech 41: 2834-2842, 2008.

23. Li J, Chen D, Tang X and Li H: On the protective capacity of a safety vest for the thoracic injury caused by falling down. Biomed Eng Online 18: 40, 2019.

24. Gertzbein SD, Khoury D, Bullington A, St. John TA and Larson AI: Thoracic and lumbar fractures associated with skiing and snowboarding injuries according to the AO Comprehensive Classification. Am J Sports Med 40: 1750-1754, 2012.

25. Nakashima D, Kanchiku T, Nishida N, Ito S, Ohgi J, Suzuki H, Imajo Y, Funaba M, Chen X and Taguchi T: Finite element analysis of compression fractures at the thoracolumbar junction using models constructed from medical images. Exp Ther Med 15: 3225-3230, 2018.

26. Qiu TX, Tan KW, Lee VS and Teo EC: Investigation of thoracolumbar T12-L1 burst fracture mechanism using finite element method. Med Eng Phys 28: 656-664, 2006.

27. Langrana NA, Harten RD RD, Lin DC, Reiter MF and Lee CK Acute thoracolumbar burst fractures: A new view of loading mechanisms. Spine 27: 498-508, 2002.

28. Wilcox RK, Allen DJ, Hall RM, Limb D, Barton DC and Dickson RA: A dynamic investigation of the burst fracture process using a combined experimental and finite element approach. Eur Spine J 13: 481-488, 2004.

29. Wagnac E, Arnoux PJ, Garo A and Aubin CE: Finite element analysis of the influence of loading rate on a model of the full lumbar spine under dynamic loading conditions. Med Biol Eng Comput 50: 903-915, 2012.

30. Fradet L, Petit Y, Wagnac E, Aubin CE and Arnoux PJ: Biomechanics of thoracolumbar junction vertebral fractures from various kinematic conditions. Med Biol Eng Comput 52: 87-94, 2014

31. Denozière $\mathrm{G}$ and $\mathrm{Ku} \mathrm{DN}$ : Biomechanical comparison between fusion of two vertebrae and implantation of an artificial intervertebral disc. J Biomech 39: 766-775, 2006.

32. El-Rich M, Arnoux PJ, Wagnac E, Brunet C and Aubin CE: Finite element investigation of the loading rate effect on the spinal load-sharing changes under impact conditions. J Biomech 42: 1252-1262, 2009.

33. Moramarco V, Pérez del Palomar A, Pappalettere C and Doblaré M: An accurate validation of a computational model of a human lumbosacral segment. J Biomech 43: 334-342, 2010.

34. Guo LX and Li WJ: Finite element modeling and static/dynamic validation of thoracolumbar-pelvic segment. Comput Methods Biomech Biomed Engin 23: 69-80, 2020.

35. Kong WZ and Goel VK: Ability of the finite element models to predict response of the human spine to sinusoidal vertical vibration. Spine 28: 1961-1967, 2003.

This work is licensed under a Creative Commons Attribution-NonCommercial-NoDerivatives 4.0 International (CC BY-NC-ND 4.0) License. 